nikom kongresu noclegi w dobrych hotelach na wrocławskiej starówce (co na spotkaniach tej rangi zdarza się bardzo rzadko), posiłki w trakcie obrad oraz komplet materiałów konferencyjnych. Opłata „wrocławska” natomiast gwarantowała posiłki w trakcie obrad oraz komplet materiałów konferencyjnych.

Kongres wrocławski cechowała bardzo sprawna organizacja, za co należą się gospodarzom szczere słowa uznania. Należy także podkreślić serdeczność i życzliwość organizatorów na poziomie czysto ludzkim, za co trzeba im również serdecznie podziękować.

Piotr Kochanek, Lublin - KUL

\title{
Sprawozdanie z wyjazdu naukowego do Rzymu doktorantów Instytutu Historii Kościoła i Patrologii KUL w dniach 5-11 maja 2019 roku
}

W dniach od 5 do 11 maja 2019 roku grupa doktorantów Instytutu Historii Kościoła i Patrologii wraz z opiekunami (ks. prof. Marcinem Wysockim i ks. dr. Marcinem Nabożnym) odbyła podróż naukową do Rzymu w ramach uczczenia 55. rocznicy założenia Instytutu Historii Kościoła na Katolickim Uniwersytecie Lubelskim Jana Pawła II.

Miejscem zakwaterowania był rzymski klasztor Sióstr Nazaretanek przy via Machiavelli 18 będący domem macierzystym tego zgromadzenia. W klasztorze tym znaczną część swego życia spędziła założycielka sióstr - bł. Maria od Pana Jezusa Dobrego Pasterza (Franciszka Siedliska). Po przyjeździe obecni na wyjeździe kapłani odprawili w kaplicy sióstr Mszę Świętą. Po krótkim odpoczynku i kolacji wszyscy udali się do miasta celem zwiedzania okolicznych atrakcji turystycznych.

Następny dzień rozpoczęliśmy Eucharystią w kaplicy klementyńskiej w bazylice św. Piotra. Modlitwa w tak znaczącym miejscu była możliwa dzięki uprzejmości ks. prał. dr. Alberta Warso, absolwenta Instytutu Historii Kościoła i Patrologii KUL, obecnie pracownika watykańskiej Kongregacji Nauki Wiary. Po Mszy udaliśmy się do siedziby kongregacji na spotkanie z jej prefektem - abp. Luisem F.L. Ferrerem SJ. W miłej atmosferze wysłuchaliśmy przemówienia arcybiskupa, po czym przedstawialiśmy tematykę naszych prac doktorskich. Następnie skierowaliśmy kroki do niedostępnej dla zwykłych turystów sali muzealnej, w której zebrano 
eksponaty związane $\mathrm{z}$ różnego rodzaju wykroczeniami przeciw wierze i zjawiskami o charakterze religijnym uznanymi przez Kościół za fałszywe. Potem przeszliśmy do jednego z pomieszczeń archiwalnych, gdzie zapoznaliśmy się z dawnym indeksem ksiąg zakazanych oraz mogliśmy oglądać półki zapełnione rzadkimi i cennymi wydaniami książek. Wśród innych odwiedzonych miejsc były również kaplica oraz sala obrad, w której dyskutowane są najbardziej palące problemy z życia Kościoła. Spotkanie zakończyło się podziwianiem panoramy Wiecznego Miasta $\mathrm{z}$ tarasu widokowego Palazzi di Sant'Uffizio.

Po opuszczeniu siedziby Kongregacji Nauki Wiary odwiedziliśmy czasową wystawę Muzeów Watykańskich, w której - z okazji obchodów 500. rocznicy śmierci Leonarda da Vinci - podziwialiśmy jedyny znajdujący się w Rzymie obraz tego renesansowego malarza przedstawiający św. Hieronima. Z kolei w położonej w pobliżu placu św. Piotra księgarni paulistów mogliśmy zaopatrzyć się w często niedostępne na polskim rynku wydawniczym pozycje książkowe zawierające najnowsze wyniki badań światowej sławy teologów.

Popołudnie poświęciliśmy zwiedzaniu zabytków Wiecznego Miasta. Pierwszym z nich był jeden $\mathrm{z}$ najbardziej znanych symbolów Rzymu Amfiteatr Flawiuszów, zwany popularnie Koloseum. Otwarcie tej wspaniałej budowli za panowania cesarza Tytusa uświetniono studniowymi igrzyskami. Następnie wyruszyliśmy w stronę Bazyliki św. Jana na Lateranie uznawanej za matkę i głowę „miasta i świata”, w której odbyło się pięć soborów powszechnych. Później udaliśmy się do sanktuarium usytuowanego naprzeciwko bazyliki laterańskiej, w którym znajdują się przywiezione przez św. Helenę z Jerozolimy święte schody, po których Jezus miał być prowadzony na sąd Poncjusza Piłata. Wspominając to wydarzenie, wierni przemierzają je na kolanach. Ze względu na olbrzymi ruch pielgrzymkowy marmurowe schody w 1723 roku zostały pokryte drewnianą okładziną mającą chronić je przed zniszczeniem. Obecnie trwa ich renowacja, dlatego osłona została zdemontowana, dzięki czemu mieliśmy niepowtarzalną okazję, by pierwszy raz na przestrzeni ostatnich 300 lat ujrzeć je w oryginale przed zainstalowaniem nowej konstrukcji ochronnej.

Trzeci dzień pobytu rozpoczął się pielgrzymką do katakumb św. Kaliksta zaliczanych do największych i najważniejszych podziemnych cmentarzy rzymskich. Pod opieka przewodnika, salezjanina z Polski, przemierzyliśmy 500 metrów podziemnych korytarzy, wzdłuż których znajdowały się nisze przeznaczone do pochówku zmarłych chrześcijan. Badacze szacują, że pochowano tam ok. pięciuset tysięcy wyznawców Chrystusa. Szczególne znaczenie dla nas miała wizyta w krypcie papieży, określanej mianem „serca katakumb”, oraz krótkie zatrzymanie się przed 
dawnym grobem św. Cecylii. Na polecenie Paschalisa I doczesne szczątki tej świętej przeniesiono do kościoła jej imienia na Zatybrzu, a w miejscu dawnej wnęki grobowej z jej ciałem obecnie znajduje się rzeźba Stefano Maderny przedstawiająca męczennicę leżącą $\mathrm{z}$ głową owiniętą chustą i związanymi rękami. Zwiedzanie zakończono wspólną Eucharystią celebrowana w jednej z podziemnych kaplic przywołującej na myśl modlitewne spotkania pierwszych chrześcijan w czasach prześladowań. Po opuszczeniu podziemi wstąpiliśmy na chwilę do pobliskiego kościółka z grobem zasłużonego dla archeologii chrześcijańskiej badacza Rzymu i odkrywcy katakumb G.B de Rossiego.

Następnie udaliśmy się do położonych nieopodal katakumb św. Sebastiana, dokąd według tradycji w połowie III wieku w obawie przed zbezczeszczeniem miały zostać czasowo przeniesione relikwie apostołów Piotra i Pawła. Dla historyków i archeologów pozostaje to do dziś kwestią sporną. Przemierzając podziemne korytarze w towarzystwie anglojęzycznego przewodnika, mogliśmy oglądać przeróżne grobowce: od bardzo prostych i skromnych wnęk zakrytych jedynie marmurową płytą bądź kamienną tablicą do bogato zdobionych i pieczołowicie dopracowanych grobów należących do osób zamożnych. Wiele płyt grobowych zawierało imiona zmarłych, fragmenty modlitw czy prośby o wstawiennictwo u Boga. Nasza wędrówka po katakumbach zakończyła się wejściem do bazyliki św. Sebastiana.

Wtorkowe popołudnie poświęciliśmy na zwiedzanie Bazyliki Matki Bożej Większej i położonego w pobliżu Papieskiego Instytutu Wschodniego. Tam właśnie odbyło się spotkanie z jego wieloletnim pracownikiem - pochodzacym z Polski ks. prof. Rafałem Zarzecznym SJ, który opowiedział nam o funkcjonowaniu uczelni. Jak się dowiedzieliśmy, Papieski Instytut Wschodni (prowadzony przez księży jezuitów) kształci duchownych i świeckich oraz publikuje dzieła naukowe na temat chrześcijaństwa Wschodu, jego historii, teologii i liturgii. Na dwóch wydziałach (Wschodnich Nauk Kościelnych i Wschodniego Prawa Kanonicznego) prowadzone są wyłącznie studia trzeciego stopnia. Mieliśmy niespotykaną okazję zwiedzić budynek instytutu, m.in. bibliotekę, która posiada jedne z najbogatszych zbiorów o wschodniochrześcijańskiej tematyce. Do spotkania dołączył na chwilę ks. prof. Marek Starowieyski, wybitny patrolog i specjalista literatury wczesnochrześcijańskiej przebywający wówczas w Rzymie.

Kolejny dzień pobytu rozpoczął się wspólną Eucharystią przy grobie św. Jana Pawła II w bazylice Piotrowej. Po Mszy Świętej mieliśmy czas na zwiedzanie tej najważniejszej dla chrześcijaństwa świątyni, zamkniętej w tym czasie dla pielgrzymów w związku z audiencją papieża Franciszka. 
Uważnie wpatrywaliśmy się w olśniewające swym przepychem i wielkością wnętrze. Szczególną uwagę przyciąga olbrzymi baldachim - dzieło wybitnego rzeźbiarza i architekta G.L. Berniniego, jak również znajdujące się we wnętrzu bazyliki rzeźby (wśród nich słynna Pietà Michała Anioła). Kolejnym ważnym obiektem w ogromnym kościele jest katedra (tron) św. Piotra, wykonana $\mathrm{z}$ marmuru i brązu kompozycja mieści w swoim wnętrzu drewniane krzesło, które według tradycji kiedyś służyło apostołowi.

Po zakończeniu zwiedzania bazyliki watykańskiej udaliśmy się do Papieskiego Uniwersytetu Gregoriańskiego, gdzie czekali już dziekan Wydziału Historii Kościoła i Kościelnych Dóbr Kultury - ks. prof. Marek Inglot SJ oraz wykładowca tegoż wydziału - ks. prof. Jan Mikrut. Ksiądz Inglot opowiedział nam historię najstarszego papieskiego uniwersytetu, omówił jego strukturę i specyfikę, zaznaczając, że obecnie studia odbywa tam ok. 3 tys. studentów z ponad 130 krajów. Międzynarodowa jest również kadra akademicka. Z kolei ks. Mikrut omówił projekt poświęcony badaniom nad dwudziestowiecznymi dziejami Kościoła katolickiego w Europie Środkowo-Wschodniej i Związku Sowieckim. Jak zaznaczył, często były to dzieje dramatyczne, naznaczone prześladowaniami instytucji i ludzi Kościoła. Rezultat wspominanych badań stanowi sześć tomów monografii wielu autorów, z których ostatni został nam zaprezentowany jeszcze przed jego premierą.

Następnym punktem naszego programu było dalsze zwiedzanie Wiecznego Miasta. Tego dnia udaliśmy się na plac wenecki, by zobaczyć słynny Ołtarz Ojczyzny, a potem na Forum Romanum. Wieczorem, po powrocie do klasztoru dzięki uprzejmości siostry przełożonej mogliśmy zobaczyć celę bł. Franciszki Siedliskiej pełną pamiątek po zmarłej w opinii świętości założycielce Zgromadzenia Sióstr Nazaretanek. Mogliśmy udać się również do innych pomieszczeń poświęconych jej pamięci i dokumentujących początki nazaretańskiej rodziny zakonnej. Zwiedzanie uzupełniała opowieść o historii zgromadzenia i jego charyzmacie. Ten dzień zakończyliśmy wspólną kolacją z siostrami.

W czwartek przed południem udaliśmy się do siedziby AVEPRO Agencji Stolicy Apostolskiej ds. Oceny i Promocji Jakości Kształcenia na Uniwersytetach i Wydziałach Kościelnych. Agencję powołał w 2007 roku Benedykt XVI jako efekt włączenia Stolicy Apostolskiej w tzw. proces boloński. Jest ona odpowiednikiem działających w poszczególnych państwach komisji akredytacyjnych. W 2018 roku jej prezesem został polski redemptorysta ks. prof. Andrzej Wodka, który teraz serdecznie przyjął naszą grupę i zapoznał nas z działalnością agencji.

Po spotkaniu i pamiątkowej fotografii powędrowaliśmy do nekropolii watykańskiej znajdującej się pod bazyliką św. Piotra. Odkryto ją podczas 
prac wykopaliskowych zleconych przez Piusa XII mających potwierdzić złożenie przy fundamentach kościoła ciała Piotra Apostoła. Słuchając objaśnień przewodnika, zwiedzaliśmy miejsca dostępne dla turystów, z których najważniejszym był grób św. Piotra.

Po krótkim odpoczynku i czasie wolnym powędrowaliśmy do Sekretariatu Stanu Stolicy Apostolskiej na spotkanie z ks. dr. hab. Waldemarem Turkiem, szefem sekcji łacińskiej zajmującej się tłumaczeniem dokumentów papieskich na łacinę. Ksiądz Turek pokazał zebranym przykładowe dokumenty wychodzące z jego kancelarii oraz mówił o potrzebie dostosowania łaciny do realiów współczesności. Tłumaczył, że proces ten niekiedy wiąże się z koniecznościa tworzenia nowych słów, które nie mają swoich odpowiedników w języku starożytnym. Tak oto powstał leksykon zawierający łacińskie neologizmy określające np. GPS czy mistrzostwa świata w piłce nożnej. Co więcej, z inicjatywy Dykasterii ds. Komunikacji Radio Watykańskie przystępuje do cotygodniowej emisji pięciominutowego programu Anima Latina, w którym ks. Waldemar będzie wyjaśniał m.in. nowo utworzone wyrazy łacińskie wprowadzane do języka w związku z treścią papieskich tweetów.

Piątkowy poranek rozpoczęliśmy od Mszy Świętej odprawionej w kaplicy polskiej w Bazylice św. Piotra. Po wspólnej Eucharystii udaliśmy się do Instytutu Patrystycznego Augustianum, gdzie tego dnia odbywała się konferencja naukowa „«Masculum et feminam creavit eos» (Gen. 1,27). Paradigms of the masculine and feminine in ancient Christianity" ( „Kobietą i mężczyzną stworzył ich” (Rdz 1,27). Paradygmaty mężczyzny i kobiety w starożytnym chrześcijaństwie'). Z uwagą wysłuchaliśmy kilku referatów wygłoszonych przez wybitnych naukowców specjalizujących się w badaniach nad spuścizną Ojców Kościoła.

Następnym punktem naszego programu dnia była wizyta w Muzeach Watykańskich. Najpierw zwiedziliśmy z przewodniczką pełen artefaktów z przeszłości starożytny cmentarz położony na terenach Państwa Watykańskiego. Potem każdy indywidualnie, w zależności od osobistych zainteresowań, rozpoczął oglądanie dostępnych ekspozycji. Wśród wielu bardzo ciekawych obiektów szczególnym zainteresowaniem doktorantów (podobnie jak i innych turystów) cieszyła się kaplica Sykstyńska ozdobiona pięknymi freskami pędzla Michała Anioła.

Nie sposób wymienić wszystkich miejsc, które udało się nam zobaczyć w trakcie tygodniowego pobytu. Plan każdego dnia był napięty i pełen ciekawych przygód. Czas wolny poświęcaliśmy na samodzielne zwiedzanie Wiecznego Miasta, które bez wątpienia można nazwać muzeum „pod gołym niebem”. Te kilka dni pozwoliło nam wczuć się w jego specyficzną atmosferę, doświadczyć jego bogactwa i różnorodności. Oprócz oczywi- 
stych walorów naukowych odbytej podróży należy podkreślić również jej korzyści interpersonalne. Czas spędzony w gronie koleżanek i kolegów ze studiów, spotkania przy stole eucharystycznym i wspólne posiłki sprzyjały wzajemnemu poznaniu się i integracji.

W imieniu doktorantów chciałybyśmy złożyć serdeczne podziękowania ks. prof. Marcinowi Wysockiemu i ks. dr. Marcinowi Nabożnemu za zorganizowanie tego wyjazdu, mając jednocześnie nadzieję, że podobne podróże staną się coroczną praktyką naszego Instytutu. Bez wątpienia był to znakomity czas spędzony w miłej atmosferze, a przede wszystkim niepowtarzalna okazja zapoznania się z funkcjonowaniem wybranych instytucji kościelnych oraz pogłębienia wiedzy teoretycznej nabytej w trakcie wykładów z historii Kościoła, zwłaszcza archeologii chrześcijańskiej. Pobyt w Rzymie stał się dla wszystkich inspiracją do dalszych studiów nad historią chrześcijaństwa.

Katsiaryna Laurynenka, Joanna Pyszna, Lublin - KUL

\section{Międzynarodowy Kongres Studiów nad Średniowieczem oraz Konferencja Studiów Cysterskich i Monastycznych, Kalamazoo, MI, USA, 9-12 maja 2019}

W drugi weekend maja, jak to już ma miejsce w długoletniej tradycji Zachodniego Uniwersytetu Michigan, USA, odbył się po raz LIV Międzynarodowy Kongres Studiów Mediewistycznych w Kalamazoo, gdzie swoją siedzibę ma Uniwersytet. Cały Kongres jest organizowany przez Instytut Mediewistyczny. Kontynuuje się tu wyrobioną praktykę organizacyjną, która rozpoczyna się we wrześniu poprzedniego roku zbieraniem propozycji wykładów (i wystaw), które następnie szereguje się i łączy w kilka bloków tematycznych. Tak powstają sesje (jedna rano, dwie po południu), każda zawierająca od 3 do 4 wykładów tematycznych. Wykład powinien trwać góra $20 \mathrm{~min}$, a po nim jest czas na 10-minutową dyskusję. Każdą sesję prowadzi osoba zaznajomiona w tematyce. Tematyka, jak zawsze, jest przeróżna, obejmuje całe bogactwo życia w średniowieczu, włącznie z życiem intymnym, seksualnym, zboczeniami itp. Pod koniec całego procesu tworzenia Kongresu powstaje specjalna pozycja książkowa zbierająca owoce prac różnych komisji, które dokonują selekcji i kompila- 